\title{
Solid-Phase Organic Synthesis of Sensing Sorbent Materials for Copper and Lead Recovery
}

\author{
M. Castillo ${ }^{a}$, G. Pina-Luis ${ }^{a}$, M. E. Díaz-García ${ }^{b}$ and I. A. Rivero ${ }^{*, a}$ \\ ${ }^{a}$ Graduate Center \& Research, Technological Institute of Tijuana, P.O.1166, Tijuana, 22000 B.C., México \\ ${ }^{b}$ Department of Physical and Analytical Chemistry, Faculty of Chemistry, University of Oviedo, \\ Av.Julián Clavería 8, 33006-Oviedo, Spain
}

\begin{abstract}
A síntese de materiais para retenção e/ou pré-concentração de espécies de interesse clínico e ambiental, como íons metálicos, constitui uma importante área de pesquisa atual. Neste trabalho, descrevemos a síntese de diferentes suportes sólidos de antraceno - sulfeto de fosfina para préconcentração de $\mathrm{Cu}$ (II) e $\mathrm{Pb}$ (II). As propriedades sensoras destes materiais também foram avaliadas usando a abordagem optosensitiva em fluxo contínuo.

The synthesis of sorption materials for retention and/or preconcentration of species of clinical and environmental interest, such as metal ions, is an important area of contemporary research. We report herein the synthesis of different solid supports of anthracene-phosphine sulfide for $\mathrm{Cu}$ (II) and $\mathrm{Pb}$ (II) preconcentration. Sensing properties of these materials were also evaluated using a flowthrough optosensing approach.
\end{abstract}

Keywords: solid phase synthesis, metal sorbents, fluorescence sensing, continuous monitoring

\section{Introduction}

Heavy metals contamination is recognized as a priority problem in environmental protection. Metal ions such as copper, lead, mercury, cadmium, cobalt etc, usually represent an environmental concern when present in uncontrolled and high concentrations. For example, elevated copper concentrations are frequently associated with leaching from antifouling paints and pressure-treated docks pilings, discharges from power and desalination plants and runoff from other land-based sources. ${ }^{1-4}$ Due to their persistence in the environment and the relatively rapid uptake and accumulation in living organisms, heavy metal ions are polluting water resources and may cause longterm risk to humans and ecosystems. The direct determination of metals in effluents or in saline matrices (e.g seawater) by atomic spectrophotometry such as flame or plasma techniques is difficult due to the nebulizer blockage, the high background, transport and chemical interferences which result in a decrease in precision and sensitivity. Therefore, separation and preconcentration methods have played a fundamental role in solving these problems.

\footnotetext{
* e-mail: irivero@tectijuana.mx
}

Solid-phase extraction is nowadays one of the interesting areas in analytical chemistry for sample cleanup. Anchoring a reactive motif to a solid support provides an immobilized active surface capable of selective and quantitative separation of cations from aqueous solution. These systems have important advantages over traditional liquid-liquid extraction or precipitation methods.

For example, they exhibit higher preconcentration factors, greater efficiency, higher reproducibility and simple handling. Among the solid materials used as sorbents for metal ions, chelating resins are extensively used due to their high selectivity. ${ }^{5}$ Although there are various chelating groups, those derivated from thiol and amine groups have high affinities towards $\mathrm{Hg}$ (II), $\mathrm{Cu}$ (II) and $\mathrm{Pb}(\mathrm{II}) .{ }^{6}$ For a rational design of a metal ion fluorescent sensing sorbent the system can be disassembled into three components as shown in Figure 1: the metal ion recognition/retention moiety, the optical reporter and the solid support.

With this in mind, Merrifield, Wang and Argogel resins, extensively used in the solid phase synthesis of many molecules, ${ }^{7-11}$ were evaluated for preparation of immobilized recognition units. Due to its strong luminescence and stability, the anthracene unit has been used as the light-emitting group and a phosphine sulfide recognition domain, with selective metal binding 


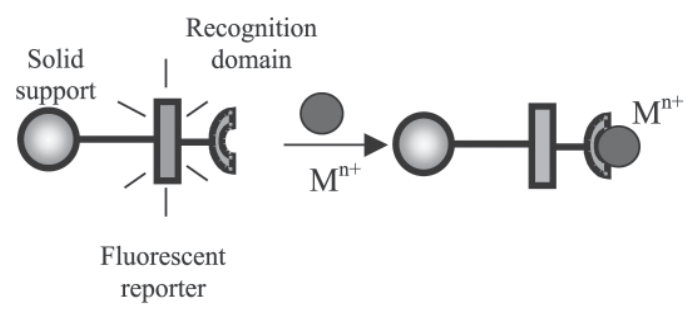

Figure 1. Principle of cation sorption and fluorescence signaling by quenching.

properties, was attached to the 9-position on anthracene, according to the synthetic route outlined in Scheme $1 .^{12}$

By exploiting the selective metal binding properties of the phosphine sulphide domain, we have sought to combine the advantegeous aspects of both fluorosensing within selective metal immobilization. In this paper insight into the sorbent and signalling properties of these materials for $\mathrm{Cu}$ (II) and $\mathrm{Pb}$ (II) in a continuous flow approach, the influence of the solid support used and their complexation behaviour towards these metal ions are described.

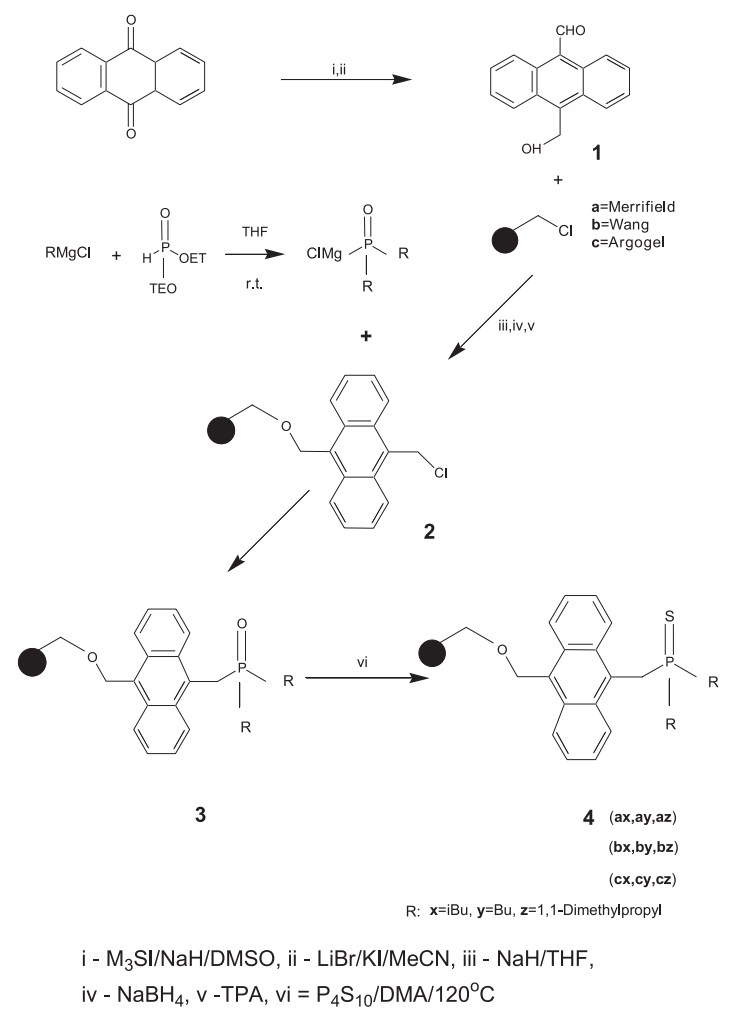

Scheme 1. Preparation of sorbent-bound indicator.

\section{Experimental}

\section{Materials}

All resins used in this work were purchased from Argonaut Technologies Inc. PS Wang (polystyrene backbone lightly cross-linked with divinylbenzene) have loading of $1.21 \mathrm{mmoles} \mathrm{g}^{-1}$, Argogel Wang (polystyrene backbone (1-2\%) cross-linked with divinylbenzene grafted

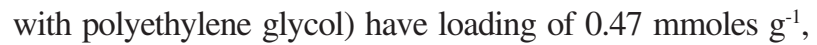
and Merrifield resins (polystyrene backbone cross-linked with divinyilbenzene) have loading of 1.19 mmoles $\mathrm{g}^{-1}$. All other reagents, if not specified, were purchased from Aldrich. All other chemicals, buffers and solvents were of analytical reagent grade and were used without further purification. All aqueous solutions were prepared using deionized water. Stantards solution of $\mathrm{Cu}$ (II) and $\mathrm{Pb}$ (II) at different concentrations were prepared in the buffer solution.

\section{Instrumentation}

All fluorescence intensity measurements were made with a Shimadzu RF-5301 PC spectrometer which has a xenon discharge excitation source (pulse width at peak half-height $<10 \mu \mathrm{s}$ ). The $3 \mathrm{~nm}$ slit width for both excitation and emission intensities were used. Instrumental parameters and processing data are controlled by the Fluorescence Data manager software. A single flow injection system equipped with a Hellma Model 176.52 flow cell $(25 \mu \mathrm{L})$ was used. Beads were washed free of any starting materials and solvents and were packed into the flow-through cell. Measures of fluorescence intensity were obtained directly from the resin beads. All experiments were carried out at $20 \pm 2^{\circ}$. $\mathrm{pH}$ measurements were made with an Orion Model 710A pH/ISE Meter. Lead and copper were estimated by Atomic Absorption spectrometer using a Varian Spectrometer AA-5 model with acetylene-air flame. Mass spectra were obtained on Agilent 1100 Series LC/ MSD Trap 9. Elemental Analyses were performed at Numega Resonance Labs. San Diego, CA. Combinatorial Chemistry was carried out in a Quest Reactor Argonaut model SLN-210.

\section{Flow injection manifold and general procedure}

The experimental set up for the system is shown in Figure 2. A Minipuls 2 four-channel peristaltic pump (Gilson, Worthington, OH, USA) was used to generate the flow stream. A type 50 PTFE four-way rotatory valve (Omnifit, Cambridge, UK) provided with a $125 \mu \mathrm{L}$ sample loop was used for solution standard introduction. PTFE tubing $(0.8 \mathrm{~mm}$ id) and fittings were used for connecting the flow-through cell, the valve and the carrier solution. The carrier buffers consisted of $0.1 \mathrm{~mol} \mathrm{~L}^{-1}$ tris $(\mathrm{pH} 7.7)$ for $\mathrm{Cu}$ (II) determination and $0.1 \mathrm{~mol} \mathrm{~L}^{-1}$ buffer ( $\mathrm{pH} 2.4$ ) for $\mathrm{Pb}$ (II) determination. Flow rate was $0.8 \mathrm{~mL} \mathrm{~min}^{-1}$. 


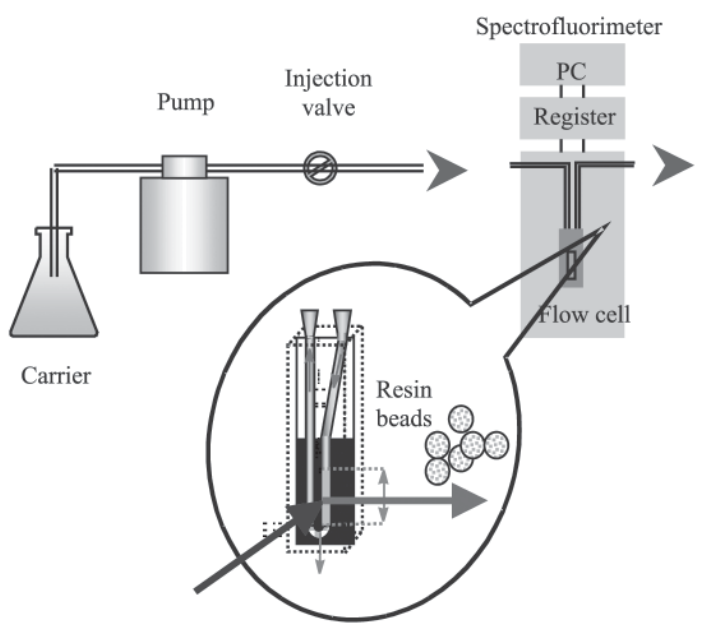

Figure 2. Flow injection optosensing set-up.

\section{Calibration}

Standard solutions of metal ions (consisting of carrier solution plus a known volume of the standard metal solution) were injected through the valve into the carrier flow stream. This stream was merged with the carrier mixed in the reaction coil and driven to the flow cell packed with immobilized resins (4a-c). Typical quenching fluorescence signals were obtained and the Stern-Volmer relationship was plotted against molar metal ion concentration.

\section{Results and Discussion}

Our synthetic route (Scheme 1) ${ }^{12}$ involves the initial reaction of anthraquinone with $\mathrm{Me}_{3} \mathrm{SI}$ in the presence of $\mathrm{NaH}$ and DMSO as the solvent at $93{ }^{\circ} \mathrm{C}$ to obtain 9,10 anthracenediepoxide (yield 82\%). This intermediate reacts with $\mathrm{KI} / \mathrm{LiBr}$ to generate 10 -methanol-9-anthracene carboxyaldehyde 1 (yield 75\%). The next reaction involves the coupling of $\mathbf{1}$ to the Merrifield, Argogel-Cl and Wang-Cl resins through a nucleophilic displacement of chloride in the presence of THF/NaH, followed of a reduction with $\mathrm{NaBH}_{4}$. The chlorination reaction is carried out in the presence of triphosgene (BTC)/triphenylphosphine ${ }^{13}$ to obtain the chlorinated resin derivatives PS-10-oxymethyl-9chloromethyl-anthracene (2a-c). Polymer-supporting yields were calculated according to Volhard titration of the residual chlorine content in the resin ${ }^{14}$ (92-99 \% conversion). The chlorinated resins were treated with phosphine Grignard previously prepared in THF to obtain PS-10-oxymethyl-9(diisobutyl-phosphine oxide-methyl)-anthracene (3a-c) (8291\% conversion). Finally, reaction of the phosphine resins with $\mathrm{P}_{4} \mathrm{~S}_{10}$ in DMA as solvent to replace the oxygen by sulphur gave the desired immobilized anthracene-phosphine sulfide resins (4a-c).The final products were washed with THF/ DCM/ $\mathrm{MeOH}$ and dried under high vacuum for $12 \mathrm{~h}$. Elemental analysis of final product were realized.

Yields and IR data are presented for Merrifield, Argogel and PS Wang-based anthracene-phosphine-sulfide final materials.

4ax. $0.47 \mathrm{~g}$ (yield $95 \%$ ); $76 \%$ conversion; IR(KBr) $v_{\max } / \mathrm{cm}^{-1}: 3058,1602,590(\mathrm{P}=\mathrm{S})$; ESIMS $(\mathrm{m} / \mathrm{z}): 377$ $\left[\mathrm{M}\left(\mathrm{C}_{23} \mathrm{H}_{37} \mathrm{PS}\right)+\mathrm{H}\right]^{+}$. Anal. calc. for polymer-supported: C, 87.91; H, 7.06; S, 2.08. Found; S, 1.58 .

4bx. 0.47 g (yield $96 \%$ ); $68 \%$ conversion; IR(KBr) $v_{\max } / \mathrm{cm}^{-1}: 3052,1109,592(\mathrm{P}=\mathrm{S})$; ESIMS $(\mathrm{m} / \mathrm{z}): 377$ $\left[\mathrm{M}\left(\mathrm{C}_{23} \mathrm{H}_{37} \mathrm{PS}\right)+\mathrm{H}\right]^{+}$. $]^{+}$. Anal. calc. for polymer-supported: C, 88.00; H, 7.01; S, 2.05. Found; S, 1.39.

4cx. $0.37 \mathrm{~g}$ (yield $74 \%$ ); $65 \%$ conversion; IR(KBr) $v_{\max } / \mathrm{cm}^{-1}: 3052,1109,592(\mathrm{P}=\mathrm{S})$; ESIMS $(\mathrm{m} / \mathrm{z}): 377$ $\left[\mathrm{M}\left(\mathrm{C}_{23} \mathrm{H}_{37} \mathrm{PS}\right)+\mathrm{H}\right]^{+}$. $]^{+}$. Anal. calc. for polymer-supported: C, 77.54; H, 7.91; S, 1.29. Found; S, 0.84.

The sulphur percentage indicates the presence of total content of isobutyl-phosphine sulfide bound to the resins. The immobilized anthracene-phosphine sulfides were cleaved from the resins by treatment with a solution of TFA:DCM (1:10) during $30 \mathrm{~min}$ in an ultrasonic bath. The resins were filtered and $1 \mu \mathrm{L}$ of the washing solution was directly injected on an ES-MS. The cuasi molecular ions $\mathrm{MH}+=369$ were obtained, verifying the presence of the phosphine sulfide group.

In Table 1 the solid supports and phosphine sulfide substituents used in the synthesis are shown.

Table 1. Fluorescent phosphine sulfide sensor library supported on Merrifield, Wang and Argogel resins

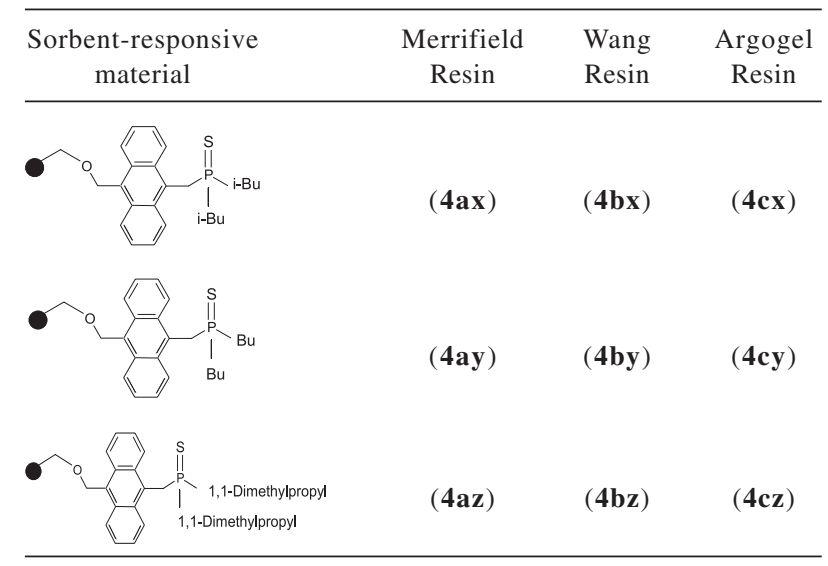

Spectral characteristics of the fluorescent sorption materials

The fluorescence spectra of $\mathbf{4 a x}, \mathbf{4 b x}$ and $\mathbf{4} \mathbf{c x}$ were obtained in order to evaluate the influence of the solid 
support on the spectral characteristics of the fluorescent materials. As observed in Figure 3, the spectra of the Argogel-based materials do not present the pattern of the structured bands of the anthracene moiety. A possible explanation could be the formation of intramolecular excimers among anthracene moieties..$^{15}$ On the other hand, the Wang- and the Merrifield-based material show the structured bands typical of the anthracene moiety. An important red shift (ca. $220 \mathrm{~nm}$ ) was observed for the Merrifield resin.

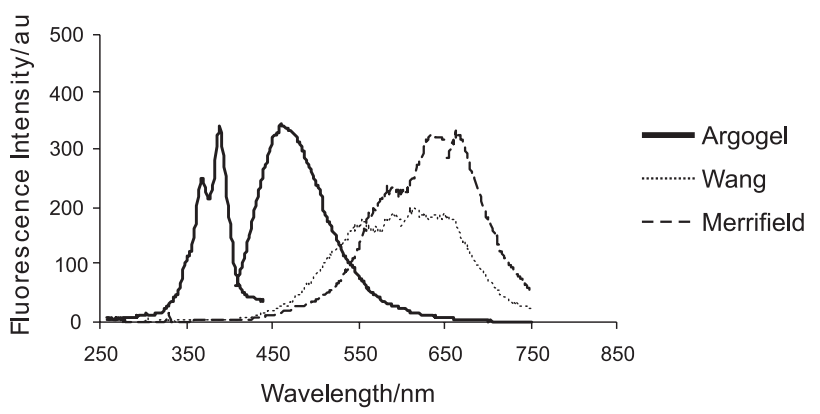

Figure 3. Fluorescence spectra of Merrifield-, Wang- and Argogeli-butyl-phosphine sulfide-based resins (4ax, $4 \mathbf{b x}$ and $\mathbf{4 c x}$ ).

Spectral fluorimetric data are collected in Table 2 in which we can observe that excitation and emission maximum wavelengths differ from that of "blank" (unmodified) resins, indicating an effective incorporation of the anthracene-phosphine sulfide onto the resins.

When considering the nature of the phosphine sulfidealkyl substituent, in the case of the Merrifield-based materials, the fluorescence is enhanced for the i-butyl group (Figure 4) compared to other substituents. This effect could be due to the proximity of methyl groups to the phosphine sulfide centre, being the spacer between them shorter in the case of i-butyl.

Table 2. Spectral fluorimetric data for resins and sorbent materials

\begin{tabular}{lll}
\hline Resin & $\lambda_{\text {exc }} / \mathrm{nm}$ & $\lambda_{\mathrm{em},} / \mathrm{nm}$ \\
\hline Merrifield (blank) & 332 & 391 \\
Merrifield-TP (4ax) & 525,637 & 668 \\
Wang (blank) & 390 & 513 \\
Wang-TP (4bx) & 550,591 & 618,660 \\
Argogel & 336 & 406 \\
Argogel -TP (4cx) & 325,390 & 462 \\
\hline
\end{tabular}

\section{Potential for continuous metal ion monitoring}

At this stage and taking into account the above results, we selected the phosphine sulfide Merrifield materials based on the $i$-butyl substituent for checking their. The

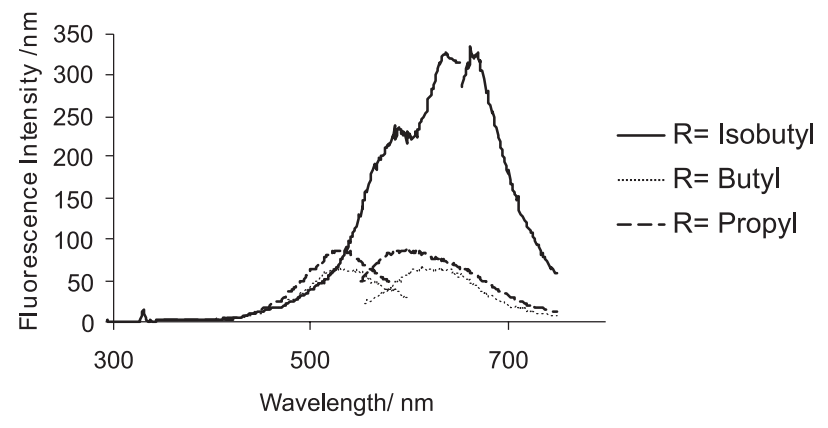

Figure 4. Fluorescence spectra of anthracene-phosphine sulfide on Merrifield resin.

effect of the solution $\mathrm{pH}$ was studied by changing the buffer carrier stream in the range $\mathrm{pH} 2$ to $\mathrm{pH} 8$.

Reversible quenching signals were observed for copper at $\mathrm{pH} 7.7$ using a tris buffer. Below this $\mathrm{pH}$, copper is permanently retained in the recognition material. Regeneration of the sensing phase could be accomplished by using acetic acid/ $\mathrm{HCl}$ or acetic acid/ $\mathrm{HNO}_{3}$ cleaning solutions. Concerning selectivity of the sensing phase, we could observe that lead quenched the 4ax fluorescence at $\mathrm{pH} 2$ and at higher $\mathrm{pHs}$ it was permanently retained in the solid. The solid can be regenerated as described above. Therefore, this sensing material may be used as selective recognition sensing phase for both copper and lead, simply by working at different $\mathrm{pH}$. In order to insight the nature of the interaction between the metal ions and the sensing moiety, a similar experiment was carried out using the intermediates 2ax and 3ax (see Scheme I) as sensing phase. Results demonstrated that fluorescence of intermediates was not quenched by copper or lead. Therefore, the fluorescence quenching of $\mathbf{4 a x}$ could be ascribed to the metal interaction through the $=\mathrm{S}$ group.

Copper and lead binding lead to an efficient quenching of the chromophore luminescence presumably via an energy-transfer mechanism. ${ }^{16}$ In order to evaluate the possibility of using this flow-through set-up to monitor the metal ions in contaminated waters, the analytical performance figures for the system using the 4ax were determined. A series of cooper ion standards, each injected in triplicate, was run on the flow injection system. The baseline was perfectly stable and the quenching response for copper resulted to be reversible. Maximum response changes were observed in less than $1 \mathrm{~min}$. A linear increase in the influent $\mathrm{Cu}$ (II) concentration (at a constant flow rate) produced a linear decrease in the fluorescence signal. A similar behaviour was observed when $\mathrm{Pb}(\mathrm{II})$ was injected. Linear Stern-Volmer calibration up to $5 \mathrm{mmol} \mathrm{L}^{-1}$ for $\mathrm{Cu}$ (II) ions $(\mathrm{R}=0.9993)$ and up to $2 \mathrm{mmol} \mathrm{L}^{-1}$ for $\mathrm{Pb}(\mathrm{II})$ ions $(\mathrm{R}=$ 0.9963 ) were obtained. The detection limit, calculated as three times the standard deviation of the base line, resulted 
to be of $6 \mathrm{mg} \mathrm{mL}^{-1}$ for $\mathrm{Cu}(\mathrm{II})$ and $7 \mu \mathrm{g} \mathrm{mL}^{-1}$ for $\mathrm{Pb}(\mathrm{II})$. The repeatability, established for 10 analyses of standard solutions containing $100 \mu \mathrm{g} \mathrm{mL}^{-1} \mathrm{Cu}$ and $\mathrm{Pb}$, was $2 \%$ for copper and $4 \%$ for lead. Sample throughput is $c a .60 \mathrm{~h}^{-1}$. In the light of these results, the optosensing system described here could be used as an "alarm sensing set-up" for copper and lead, for which regulated effluent limitations exist. ${ }^{17}$

\section{Sorption characteristics}

The influence of the $\mathrm{pH}$ on the sorption of copper and lead by the different phosphine sulfide resins $4 \mathbf{a x}, \mathbf{4 b x}$ and $\mathbf{4 c x}$, was studied. The retention of both metal ions increases with increasing $\mathrm{pH}$, having a maximum value of $40 \%$ for lead at $\mathrm{pH}>5$ and $70 \%$ for copper at $\mathrm{pH}>6$.

The sorption of $\mathrm{Cu}$ (II) and $\mathrm{Pb}(\mathrm{II})$ at the optimum $\mathrm{pH}$ on the phosphine sulfide resins was studied by batch method. Each portion of $50 \mathrm{mg}$ of phosphine sulfide resins was weighed accurately and transferred into a $50 \mathrm{~mL}$ polyethylene vial equipped with a polyethylene screw top. Then $20 \mathrm{~mL}$ a copper or lead stock solution of a given concentration at the optimum $\mathrm{pH}$ was added. The reaction mixture was subjected to mechanic shaking for 2 to $24 \mathrm{~h}$. The concentration of copper and lead in the supernatant was determined by atomic absorption spectrophotometry. The amount of metal adsorbed by the phosphine sulfide resins was calculated from the differences between metal quantity added to the resins and metal content of the supernatant using the following equation:

$\mathrm{Q}=\left(\mathrm{C}_{0}-\mathrm{C}_{\mathrm{f}}\right) * \mathrm{~V} / \mathrm{M}$

where $Q$ is the metal uptake $\left(\mu \mathrm{g} \mathrm{mg}^{-1}\right) ; C_{0}$ and $C_{f}$ are the initial and equilibrium metal concentrations in the solution $\left(\mu \mathrm{g} \mathrm{mL}^{-1}\right)$, respectively; $V$ is the solution volume $(\mathrm{mL})$; and $M$ is the mass of sorbent (mg).

Results are summarized in the Table 3 , in which the time of contact between the metal ion solution and the resin material were considered. Data in Table 3 clearly demonstrate that the Wang-based material is superior to the Merrifield one for quantitative sorption of both metal ion species. This fact can not be explained by a complexation effect as the phosphine sulfide substituent was kept the same. On the other hand, the use of ultrasonic bath agitation showed an improvement of the retention of 1.7 times at 30 minutes from a $20 \mu \mathrm{g} / \mathrm{mL}$ copper solution in contact with $50 \mathrm{mg}$ Merrifield resin-phosphine sulfide. Therefore, it may be rationalized considering that the accessibility to the reactive groups by the metal ions depends on the porous nature of the solid support. It is known that more than $99 \%$ of the reactive binding sites on resin beads are located into the microporous of the resin ${ }^{18}$ and reactions at these sites are diffusion controlled. ${ }^{18,19}$ As a result, the use of ultrasonic agitation seemed to increase the bead fluidity and the diffusion process. Complete desorption of sorbed copper and lead took place with 0.1 mol L-1 acetic acid/ $0.1 \mathrm{~mol} \mathrm{~L}^{-1} \mathrm{HCl}$ or $0.1 \mathrm{~mol} \mathrm{~L}^{-1}$ acetic acid $0.1 \mathrm{~mol} \mathrm{~L}^{-1}$ nitric acid mixtures (2h stirring contact time). The order of affinity $\mathrm{Cu}(\mathrm{II})>\mathrm{Pb}$ (II) may be interpreted on the basis of Pearson's theory according to which ligands containing sulfur coordinate soft acids like $\mathrm{Cu}$ (II) and $\mathrm{Pb}$ (II) ions in correspondence with their size and deformability. ${ }^{20}$

\section{Conclusions}

Concluding, phosphate sulfide receptors bound to different solid supports were synthesized and their properties as sensing phases and chelating resins towards $\mathrm{Cu}$ (II) and $\mathrm{Pb}$ (II) metal ions were evaluated. The responsive materials showed quantitative retention properties which can be improved with the use of ultrasonic bath agitation. The potential use of the materials for in-situ immobilization and for fluorimetrically monitoring of toxic metals such as copper and lead was screened using a high-throughput flow injection format. Although our work solely describes measurements of copper and lead, application for immobilization and analysis of other metal ions ( $\mathrm{Zn}, \mathrm{Co}$, $\mathrm{Cd}$ etc) can be envisaged. The results presented in this paper will undoubtedly form the foundations for future approaches capable of monitoring lower concentrations of transition metal ions in real-time and real-space.

\section{Acknowledgment}

Authors gratefully acknowledge support for this project by Consejo Nacional de Ciencia y Tecnología, México

Table 3. Retention of metal ions on $i$-butyl-phosphine sulfide-based resins

\begin{tabular}{|c|c|c|c|c|c|c|c|}
\hline Resin & Metal & $\mathrm{pH}$ & {$[\text { Metal }]_{\mathrm{i}}^{\mathrm{a}}$} & $\% \operatorname{Ret}^{\mathrm{b}}$ & $\% \operatorname{Ret}^{\mathrm{c}}$ & $\% \operatorname{Ret}^{\mathrm{d}}$ & $\mathrm{Q}\left(\mu \mathrm{g} \mathrm{mg}^{-1}\right)$ \\
\hline MF-TP & $\mathrm{Cu}$ & 6 & 20 & 11,5 & 25 & 52 & 4.12 \\
\hline W-TP & $\mathrm{Cu}$ & 6 & 22.6 & - & 70 & 89 & 8.04 \\
\hline MF-TP & $\mathrm{Pb}$ & 5 & 23.0 & 20 & 34 & 38 & 3.45 \\
\hline W-TP & $\mathrm{Pb}$ & 5 & 23.4 & 21 & 61 & 82 & 7.60 \\
\hline
\end{tabular}

${ }^{\mathrm{a}} \mu \mathrm{g} \mathrm{mL}-1$; ${ }^{\mathrm{b}} 2 \mathrm{~h}$ contact; ${ }^{\mathrm{c}} 12 \mathrm{~h}$ contact; ${ }^{\mathrm{d}} 24 \mathrm{~h}$ contact; MF: Merrifield resin; W: Wang resin; TP: phosphine sulfide receptor. 
(CONACyT, GRANT No 28488-E) and Consejo Nacional de Educación Tecnológica, México (COSNET, GRANT No. 23.97-P). M.Castillo thanks CONACYT for a graduate fellowship.

\section{References}

1. Paquin, P.R.; Santore, R.C.; Wu, K.B.; Anid, P.J.; Kavvaas, C.D.; DiToro, D.M.; Environ. Sci. Policy 2000, 3, S165.

2. Stephenson, T.; Heavy Metals in Wastewater and Sludge Treatment Processes; CRC Press: Boca Raton, Fl, 1987, vol.1 (Sources, Analysis and Legislation).

3. Kennish, M.J.; Estaurine and Marine Pollution, CRC Press: Boca Raton, FL, 1997.

4. Negri, A.P.; Heyward, A.J.; Mar. Environ. Res. 2001, 51, 17.

5. Garg, B.S.; Sharma, R.K.; Bhojak, N.; Mittal, S.; Microchem. J. 1999, 61, 94.

6. Kantipuly, C.; Katragadda, S.; Chow, A.; Gesser, H.D.; Talanta 1990, 37, 491.

7. Obrecht, D.; Villalgordo, J.M.; Tetrahedron Org. Series, Pergamon Press: Oxford, 1998, vol. 17.

8. Dolle, R.E.; J. Comb. Chem. Rev. 2000, 2, 383.

9. Sammuelson, R.E.; Kurth, M.J.; Chem. Rev. 2000, 101, 137.

10. Vélez López, E.; Pina-Luis, G.; Suárez-Rodríguez, J.L.; Rivero, I.A.; Díaz-García, M.E.; Sens., Actuators B 2003, 90, 256.
11. Pina Luis, G.; Badía, R.; Díaz-García, M.E.; Rivero, I.A.; J. Comb. Chem. 2004, 6, 391.

12. Rivero, I.A.; Castillo, M.; Pina-Luis, G.; Proceedings of the Referred Abstracts of the III Simposio Internacional: Investigación Química en la Frontera, Tijuana, Baja California, México, 2000, p. 151.

13. Rivero, I.A.; Somanathan, R.; Hellberg, L.H.; Synthetic Commun. 1993, 23, 711.

14. Stewart, J. M.; Young, J. D.; Barany. G.; Solid Phase Peptide Synthesis, W.H. Freeman: San Francisco, 1969.

15. Lakowicz, J.R.; Principles of Fluorescence Spectroscopy, $2^{\text {nd }}$ ed., Kluwer Academic/Plenum Publishers: New York, 1999.

16. Granda Valdes, M.; Badía, R.; Pina Luis, G.; Díaz-García, M.E.; Quím. Anal. Int. Ed. 2000, 19, 38.

17. Revised Guidance Manual for Selecting Lead and Copper Control Strategies; Office of Water (4606M), EPA-816-R-03001, www.epa.gov (accessed on December, 2003).

18. Li, W.; Yan, B.; J. Org. Chem. 1998, 63, 4092.

19. Yan, B.; Fell, J.B.; Kumaravel, G.; J. Org. Chem. 1996, 61, 7467.

20. Lezzi, A.; Cobianco, S.; Roggero, A.; J. Polym. Sci., Part A: Polym. Chem. 1994, 32, 1877.

Received: December 15, 2004 Published on the web: April 12, 2005 